\title{
European Multiculturalism: Between Unity and Exclusion
}

\author{
Erhan Tecim, Müserref Yardim \\ Department of Sociology, Necmettin Erbakan University, Konya, Turkey
}

Email address:

etecim@konya.edu.tr (E. Tecim), myardim@konya.edu.tr (M. Yardim)

\section{To cite this article:}

Erhan Tecim, Müserref Yardim. European Multiculturalism: Between Unity and Exclusion. Psychology and Behavioral Sciences. Vol. 5, No. 1, 2016, pp. 12-19. doi: 10.11648/j.pbs.20160501.13

\begin{abstract}
This study addresses the immigrant issues in European countries. It attempts to mostly evaluate the developed European countries. After the world wars, the need for labor force emerged in developed European countries. Those countries demanded a high amount of qualified labor force from Turkey and other Muslim countries through agreements signed. Decreased birth rate and increase of elderly population constitutes a really big dilemma for European countries. Such that increased labor demand of European countries has not yet reached an optimum level. Not soon after the immigration traffic, main culture and compliance issues have arisen among immigrants, and they have tried to overcome such issues. Many attempts have been made to overcome the real problems that still exist today. For solving such problems, different methods have been tried such as assimilation, integration and lastly multiculturalism. Historically, this process emerges as an issue on which consensus could not be reached in Europe even in 2015. The most obvious signs of this situation particularly include the harshening rhetoric of the extreme right-wing party leaders in various European countries as well as the rise of social acceptance rate of these parties. Though they were invited to the host country by private agreements and welcomed with flowers, those people are still described by the host culture and official authorities as 'foreign' or 'immigrant workers', which imply alienation. Considering the problem stated above, this article is intended to investigate this historical experience.
\end{abstract}

Keywords: Multiculturalism, Immigration, Exclusion, Integration, Islamophobia

\section{Introduction}

After having completed the industrialization, European countries have begun to face difficulty in finding labor force as a consequence of the mass deaths due to the war. In search of labor force, the European countries have started looking for opportunities to supply the labor force demand. In order to close the existing labor force gap, they sought to obtained skilled workers from other countries.

In this way, migration has come to the agenda of the European Community since the second half of the 20th century for the first time. The European Economic Community promoted people to encourage emigration to other community members. For example, the Rome Convention was signed on March 20, 1957 with the aim of promoting people in member countries for mobility for workers. The Convention not only discusses the concept of 'Union citizenship' but also many other topics such as transportation, agriculture, family life, free movement of individuals, free movement of goods and capital, culture, public health, education, young people's situation and environmental issues.

The Single European Movement of 1986 expanded the Rome Convention ensuring the taking of firm steps towards today's European Union. In following negotiations and agreements, these issues were elaborated and continued to be discussed in detail. In 1992, the Maastricht Convention brought a new approach to the definition of citizenship; thus the citizenship of the European Union emerged granting them more rights. The main objective of the agreement was to create a new European Union identity. However, it was desired to be built without compromising national harmonization of the member states or conflicting with national culture. In this process, citizenship of the European Union was promoted as an upper identity. Then, the Amsterdam Treaty brought its macro benefits to the forefront in 1999. This has brought with it the right to be a member of the European parliament and voting.

\section{The Labor Force Welcomed to Europe}

The European Community Commission awarded its nation-states the freedom to deal with this issue on their own 
measure. As a result, member states of the Community began to announce their own agendas on immigrants in parallel with their individual economic situation.

The labor movement is basically defined in an order from the second to the first or from underdeveloped to developed in a lateral axis from the periphery to the center. According to such a placement; the Netherlands, Germany, Switzerland, France and Sweden are considered as the "central" countries of the Continental Europe; whereas Italy, Spain, Portugal, Greece, Yugoslavia and Turkey are referred to as "peripheral" countries in the Continental Europe (Çağlar \& Soysal, 2003: $5)$. Yet, these countries could not meet the labor needs of the Western Europe, either. Thus, most North African countries and even India and Pakistan as well as many Arab countries were applied to import laborers into the central European countries. The fact that majority of the immigrants were Muslims brought along different discussion topics to the political and intellectual agenda.

Some theories of immigration explain migration in classical terms in the context of the driving factors and attractive factors. The pushing factors in migration arise from the homeland and are basically associated with the lack of unemployment or salary. In this way, poor people want to migrate to developed countries where they can get better jobs and salaries than in less developed countries. Escape from poverty can be seen as an ancient driving factor. Abundance of jobs and high level of prosperity are seen among attractive factors. Fichter stressed that there is a myriad of reasons pushing people to migrate from one country to another and these factors are too complex; nevertheless, the economic factor is traditionally decisive (Fichter, 1990: 143).

In the specific example of Germany, it is seen that Germany signed a labor agreement with Italy in 1955 to meet the need for labor; and it further signed similar agreements with Greece and Spain in 1960, Turkey in 1961, Morocco in 1963, Portugal in 1964, Tunisia in 1965 and Yugoslavia in 1968. Though not given an exact number, it is estimated that currently 3.5 million Muslims live in Germany. Not all of the immigrants living here are, of course, workers. While only migration of workers was in question for both parties before, the migration of workers' families has started over the years. It is observed that social and cultural problems have reached its peak following the migration of families (Aktürk, 2006: 8; Haksever, 2014: 1).

France has quite a long history of immigrants. As a result of the industrialization emerging in early 18th and 19th centuries, labor demand appeared in overall Europe particularly including France. The only reason for this emerging labor force need may not be the industrialization itself. The decrease in birth rates depending on the social structure brought about by industrialization should also be kept in mind because it is obvious that labor force will decrease in parallel with decreased population of young people.

When labor force need is in question, "Europe opens up its doors, but what was its attitude like about immigrants' rights?" "They will ensure the protection of human rights" replied the
European Union countries, which are signatories of the Amsterdam Convention. This issue- safeguarding of people's social, civil and political rights- is also guaranteed by another agreement (European Union Charter of Fundamental Rights, 1999). The rights of the immigrant workers within the Union are also guaranteed as a result.

However, there is a major problem, which was discussed and solution was sought until the end of 1970: The issue of shortcoming of labor force within the European Union countries and precautions that can be taken accordingly.

\section{European Muslims Squeezed Between Integration and Assimilation}

European Muslims are various in ethnic and cultural terms. In this regard, the largest group is consisted by North African Arabs, and they are followed by the Turkish. In general, density of Turkish population in Europe can be explained with Germany's labor-immigration policy. Another group consists of people from the Indian subcontinent and particularly Pakistanis (Hunter, 2002: 11-15; Kivisto, 2002: 162).

In reality, the reality of Islam in Europe poses a wide variety in itself. This diversity can be based on cultural, national, religious and linguistic facts. In said diversity, while ethnicity remains important, there are other groupings in mosques or unions- associations on the other side. Such groupings are more important than thought.

When we look at the demographic position of Turks in Europe, it can be seen that they have a more advantageous position than other immigrants and ethnic groups. While ethnic groups such as Pakistani, Indian, Iran, Arab, Chinese and Moroccan are limited to a few countries, Turkish people have settled in almost every country in Europe (Hunter, 2002: 11-15). In addition to the demographic status, Turkish immigrants are also awarded citizenship in their host countries in Europe. This involvement brings along unity in the social, political and economic life. Yet, the second and third generation Turks in Europe have not been able to create a perception of Islam beyond the nation-state. Although it is said to be affected from different ethnic and cultural policies of the European states, it is really important that immigrants are regarded as a threat.

The fear from immigrants is rooted in the European society due to the perception of immigrant. The immigration policies applied by relevant authorities play an important role in the formation of the perception of immigrant. In this regard, the term "adaptation", "integration", comes as the key word.

Cultural integration is concerned with the relationships and compliance between the compliance of immigrants and immigrant communities with local values, rules, and behavioral models. It is also connected with the reactions created by the host society for the manifestation of the cultural life of the immigrants. The home of cultural integration is civil society and it is increasingly becoming the media - in today's world. Successful and positive cultural 
integration clearly shows itself in strong ethnic relations. Immigrants manage to enter various sectors, enterprises, institutions and organizations through structural integration and they create the parallel forms of these institutions. Such sectors, institutions and organizations include economy, education, political parties and religious communities. On the other hand, partnership in the local labor market is one of the most important indicators of structural integration. Political integration refers to the ways that the state cooperates with immigrants. Certain issues require participation to the host society in its entirety, and encompass obtaining of citizenship and other legal rights. Thus, it is equally important that immigrants become political decision-makers for themselves. Not only making up laws against discrimination but also opportunities or limitations regarding obtaining citizenship are integral parts of political integration (Martikainen, 2010: 266).

Policies and practices regarding immigrants implemented in European countries vary from period to period. Although each country implements its own program, they can be categorized in a particular way. European countries thought that they could assimilate the first wave of immigration in political and intellectual aspects; in other words, they expected that these new arrivals from less developed cultures would melt in the high culture of the host countries.

It can be said that immigrants and Muslim hostility have constituted the main theme of far-right rhetoric for many years. However, the debate is now over improbability of immigrants' compliance with Europe due to their cultural identity conflicting with the European liberal values, rather than how immigrants fit into the European society (Wilson \& Hainsworth, 2012: 3).

Today in Europe, being "immigrant" and especially being Muslim still identified as immigrant means being the "other" in Europe. In other words, the perception holds ground across Europe that Muslim could not adapt to the values of European society due to their religion and culture. Hence, the slogan "love it or leave" (Libération, 25 November 2009) constitutes the basis of extreme right-wing rhetoric and it shows that the issue of integration of the Muslim is dealt in a pro-assimilation framework in fact. In short, there is the truth of the "Muslim issue" marginalized as "immigrant question" by Europe. This problem is used to create a "horror wave" by many groups mainly including the extreme right. For example, many political parties in France, particularly the extreme right-wing National Front led by Jean-Marie Le Pen promotes discrimination against immigrants under the pretext of protecting the French culture (Semenkovich, 2006: 7). However, the discrimination has brought along collection of immigrants in particular centers within France. This density and immigrant culture can be listed among the main causes of contemporary problems of France and almost many other European countries. In the 90s, the extreme rightist National Democrat Party in Germany arranged extremist organizations that attract neo-Nazis. Moreover, even the Christian Democrats as a center party argued that they would reduce immigrants (Kivisto, 2002: 170).

The racist and extreme right-wing parties are now rising and gaining victory in elections, such as the results of the European Parliament elections by 28 European countries in May 2014, although they were considered marginal until recently. Such results are considered worrying as they seem to be fuelling hate speech. The leading reason for the rise of extreme right can be the nationalist rhetoric they use. Besides the desire to terminate the Union, the common discourse of the racist and extreme right parties in Europe triggers nationalism consequently promoting opposition to all kinds of ethnic, cultural and religious differences. The main theme of the politics founded on foreigners and immigrants is centered on Muslims (Yardım, 2014: 13).

It is thought that the victory in the elections of the extreme right parties in Europe is not for once or a temporary responsive phenomenon. Rather, it suggests that such parties benefit from actual institutionalization among European parties. Extreme right-wing parties in Europe seem to have three main characteristics: 1. Populism based on frankness and anti-elite rhetoric, 2. Authoritativeness, and 3. Nativism (Wilson \& Hainsworth, 2012: 3).

Extreme rightist rhetoric is becoming more popular day by day in Europe. It is seen that not only the center party but also the party in power are affected from the extreme right party rhetoric. They argue "far-right parties are asking the right questions, but they do not give the right answers" rather than offering solutions for political and social problems" (Wilson \& Hainsworth, 2012: 2).

Across Europe there is a common stereotype about migrants: Immigrants must either be assimilated or they must maintain their 'traditional lifestyles' in the host society. Particularly this can be said to be a stereotype offering a cultural "other". However, the real life is very different. Most immigrants try to maintain some aspects of their history. Still, they actively endeavor to try new practices. It is also true for issues related to religion. If the dominant community does not support immigrants' religious and cultural practices, this situation inevitably will lead to some changes. This cultural integration process related to religion is referred to various names such as 'enculturation' (cultural integration), 'contextualization' (fitting conditions, contextualization) 'indigenization', and 'syncretism' (Wamer, 1998 cited by Martikainen, 2010: 270).

According to Türkdoğan (1998: 33), assimilation means combination of two or more groups in one group; penetration of different customs, attitudes, ideas and social relations into each other towards a common association. Full assimilation of two ethnic groups can be complete when cultural differences stop existing which is mainly based on ethnic and physiognomic origin also covering the social status. It goes without saying that such cultural 'ending' refers to the melting of the immigrants' national culture within the main culture.

In this regard, Nilgün Çelebi regards ethnicity associated with identity search. Immigrants' adaptation to the culture of the society in which they moved has brought them an "ethnic consciousness" beyond assimilation. The identity search process is a reflection of the "ethnic consciousness" which emerged in Western Europe (Türkdoğan, 1998: 72). 
In the context of assimilation, language problem can also be said to be an important factor. The first generation of immigrants tried to learn a new language as much as they needed, as a result, they did not learn it completely. However, the situation was much more different in the 2nd and 3rd generations: some could speak both languages very well, while there were some immigrants who could learn neither mother language nor host country language.

According to Meisel (1990: 42-45), the language problem faced by immigrant children in Germany can be summarized under three main points: First; especially the young people's everyday language is increasingly becoming a blended language with the mixed German-Turkish as well as Turkish slang. Immigrant children try to combine the two languages (fusion) since they failed to learn well the grammar of both languages. Secondly, they prefer to speak German because they do not want to use German words during their talk in Turkish (code-switching) when they do not remember certain words. Lastly, some immigrants display code-mixing which refers to two separate structures as in the code-switching. In the latter case, unlike code-switching, certain deficiencies occur during the use of language in the systematic structure and speakers try to correct such deficiencies with skills in the other language.

As a result of this linguistic differentiation; having different religious, socio-cultural and political values adversely affected the opening of immigrants into the German society and the Turkish community started forming associations in themselves. The danger of melting away in the new society and similar worries caused nationalist, religious, social and cultural structuring among workers. Such reflex and emotions have played a decisive role in forming up of associations. However, immaturity of such feelings has brought along certain problems (Polat, 2007: 332).

The European Union has tried to follow immigration policies based on "adaptation" and "integration" outside "assimilation", but it proved unsuccessful as well. Then, the Union has started to search for the ways of in "living together" in the context of "multiculturalism". On the other hand, some changes were made in immigrant policy to interrupt the migration wave. Despite the difficulty of limiting the wave of immigration from outside, some inherent limitations can be very easy to the established public or politicians. Still, Europe may not easily close its doors and borders without exerting any effort.

\section{Europe's Ideal of Multiculturalism, the Beginning of the End}

The first step in the multiculturalism journey in Western Europe has become the recognition of minority groups. Even though the Helsinki Final Act objective to remove minorities from a security speech act is not fully realized, the 1990s has come to mean inclusion of minorities in the citizenship scope at least in West Europe. The definition of people in Western European countries has begun to refer to all of the people living in the country rather than merely an ethnic, religious, linguistic or historical bond, or a specific nation. Being included in the process called Europeanization; the policies to be implemented on minorities are collected under mean headings of 'recognition', citizenship and 'recognition' of the concept of citizenship and European integration. Here comes to mind questions such as "Who are the minorities?" and "Are immigrants among well-known minority groups?" (Ongur, 2011: 69-70).

The second major source of multiculturalism in Europe is constituted by immigrants or minorities with immigrant background. The cultural diversity reflected by those groups mostly arises from international migration which starts at individual level and continues with family reunion. As a product of a series of migration started after World War II, the "new" minorities are defined in different ways in different European countries. They are referred to as "foreigners" in countries like Germany, Belgium and Switzerland; "migrant workers" in France; "immigrants" in the Netherlands and Sweden, while the term "racial minorities" is preferred in England (Entzinger, 1984: 166-67). In the current and political life, emphasizes in the use of this diversity has gained a special importance. If you want to emphasize the immigrants' origin, it is not minded to call as "foreigners" or "immigrants". However, if you want to define these groups as a part of the society, the concepts become useless and even inconvenient. Then, one had better use other terms such as "new minorities", "ethnic and cultural groups" or "nationals". Emphasizing of the terms in a particular way expresses a political stance in some cases. For instance, racist and xenophobic groups particularly repeat the term "foreigners" in any environment in order to emphasize that immigrants are not integral parts of the European community (Canatan, 2009: 81).

There are three basic options for modern states when it comes to the immigrants: discriminatory exclusion, assimilationist and multicultural models. The discriminatory exclusion model is the condition where immigrants are allowed to enter particular areas of the community (eg, labor market), while restricting entry to some other areas (e.g., health care and citizenship). Such countries include countries such as Germany and Austria in the West, which accept traditional guest-workers. The assimilationist model can be described as one-sided integration with expectation of immigrants alike the majority. The best example of this model in contemporary Western society can be said France. But this approach is mostly abandoned in the West. The multiculturalist (pluralist) model largely embraces cultural diversity, still with ongoing expectations for loyalty to the state. Most of the large-scale immigration countries adopt a multicultural approach, at least to some extent (Castles \& Miller, 2003 cited by Martikainen, 2010: 272).

However, multiculturalism has gained a new dimension with Cameron, Merkel and Sarkozy's statements. Following frequent explanations of Angela Merkel pointing out failure of multiculturalism, British Prime Minister David Cameron also stated that the multiculturalism policy proved unsuccessful at the Munich Security Conference that took 
place in February 2011. In his speech, Cameron said that financial resources for the fight against extremism in all its forms mainly including the Islamic fanaticism would be cut, and certain precautions would be taken to prevent spread of these approaches at the institutional level. He added that different segments of the society are fragmented due to the practices of multiculturalism, which in turn triggers anarchism. He defended that construction of a strengthened national identity may remedy this situation. The politicians arguing that multiculturalism fails to organize the life of European societies receive support from not only Germany and England but also many other European countries such as Denmark and France (İnanç \& Çetin, 2011: 24). Moreover, it is seen that in his statement referring to the bankruptcy of multiculturalism, then French President Nicolas Sarkozy underlined the need to do it around Islam and Muslims in the context of France (Le Figaro, 15 Şubat 2011).

When immigrants and especially Muslims are concerned, it is noticed that the concept of "integration" is referred to in the same context as assimilation, acculturation, adopting of European values and social harmony. Yesterday's racism which wants to deny the citizenship of immigrant workforce has turned to today's "nativism". The idea of "nativism" expresses the other face of racism, and while it attempts to create a homogeneous society, it first wants ethnic minorities to wash out from their own culture and shape themselves according to the European image before being integrated into the society. Integration problem depends on the interpretation of the concept of integration (Fekete, 2008: 1). Hence, assimilation and cultural homogeneity have the same meaning as integration (Fekete, 2008: 10).

It is often voiced that the assimilationist policies put into practice under the name of integration in the European Union countries increase suspicion and hostility towards the fourth generation of Muslims who are still regarded as immigrants.

Muslims in the European Union: Discrimination and Islamophobia, in a report on the situation of Muslims in the Member States, The Europe Racism and Xenophobia Monitoring Centre (EUMC) indicates that xenophobia is linked to Islamic hostility and Muslims become victim of discrimination as a result of the hostilities in European societies. Thus, according to the EUMC, "Many European Muslims, regardless of their ethnic identity and/or religious approach, are facing discrimination in employment, education and housing areas; though limited data exist regarding religiously aggravated incidents, it is known that Muslims are exposed to Islamophobia ranging from verbal threats to physical attacks. Discrimination against Muslims can be attributed to racism and xenophobia besides Islamophobic attitudes as they are often intertwined with the latter. Therefore hostility against Muslims needs to be dealt in a wider scope in a way to cover xenophobia and racism against immigrants and minorities" (EUMC, 2006).

European Union countries have recently started to introduce new standards to the immigration application and decided to follow a selective immigration policy in order to preserve their national identity and strengthen their economies. This decision cannot be said to be immune from effects of the September 11 attacks. Muslim immigration to the European Union today is restricted by law and practically. The immigrants already living in Europe experience difficulties related to housing, civil rights, employment and religious practices.

It is clear that xenophobia and ethnic discrimination have increased especially since September, 11. However, the attacks in Paris on November 13 may serve to further accelerate the process. Many employers remain reluctant to hire Arabs. For example, discrimination actually continues in employment and social life in France, though not in legal terms (BBC News, 2005). Another consequence is that immigrants are pushed to live in poorer homes outside the cities where the host culture is not widespread and security is weak in France as well as other European countries since homeowners do not want to hire their homes to Arabs and Muslims or other ethnic minorities (Semenkovich, 2006: 6).

Under the rhetoric of multiculturalism lies the will to shake off the traditional (nationalist) identity perception which suggests that multiple cultures (nations) cannot live within the limits of given (national) borders. According to Williams, "Speech acts of the nationalist discourse can be cleared off and thus more peaceful interstate relationships can be achieved only by giving more political and social rights to different identities, cultures and nations and not turning a blind eye to their forced assimilation, social suppression and denials" (Ongur, 2011: 60).

How can the targeted multicultural life be explained in the face of the increasingly obvious reality of Islamophobia and xenophobia in Europe? In the spread of Islamic art and culture in Europe, the presence of Muslims in Spain and Sicily, that is the effect of internalization of the IslamicSpanish culture by Europe, cannot be ignored. Then, what has changed since the $11^{\text {th }}$ century when Islam and Muslims were superior in technological and cultural sense and European people regarded Muslims inaccessibly superior? (Watt, 1989: 7) Doubtlessly, a lot has changed in sociopolitical and technological/scientific terms. The roles, content, arts, perspectives of civilizations have changed since then. From the Western point of view, the world is tangible, science is material and it explains many things.

Departing from this, the roots of Western prejudice against Islam and Muslims can be looked up in the history of the spreading of Islam and establishment of a new civilization. The stance against Islam became even deeper as a consequence of the Crusades, reaching its peak with moving of Muslims to the center of Europe through Spain, Istanbul and the Balkans until the $19^{\text {th }}$ century.

Receiving both philosophical and theological support, the thought of İslamophobia maintained its popularity during the Middle Ages. Martin Luther's discourses and theologicalphilosophical traditions should be taken into account in understanding religious, political and sociocultural dynamics of the contemporary western civilization. By combining theology with politics, Luther has been one of the pioneers of the idea that lays politics on theological data. From time to 
time, Luther used the term 'Turkish' or 'Turks' to refer to Muslims; in this way, he identified the concepts of 'Muslim' and 'Turk' and together with the popery he considered Turks as a common enemy (Hidir, 2007: 145). Then, roots of the hostility towards foreigners and Islam can be traced to back to Martin Luther.

Then, 'Where exactly is multiculturalism within Islamophobia?' It is seen that there is no need to go back far to the very roots of multiculturalism in Europe. Michell Wieviorka notes that this concept was inconspicuous even in 1960; whereas Nathan Glazer dates back the emergence of the concept as far as to 1941; however, Wieviork indicates that the concept of multiculturalism was not used as an adjective to describe the state or the society even in early1970s. He believes that the term multiculturalism first entered in the dictionary of sociology as late as 1990s. ${ }^{1}$ On the other hand, Hussain and Miller (2006: 50) point out that discussion of the concept in England dates back to 1960s. Moreover, in 80s, Interior Secretary Joy Renkins drew a sharp line between assimilation and integration and stated that integration would not lead to losing of national character and identities of minorities. Also Renkins discussed integration in relation with culture and equality of opportunity and addressed the mutual tolerance rather than a way of boosting assimilation.

According to Mark Lopez (2000: 22-24), the multicultural ideology was introduced by a small group of scholars between the years 1966 and 1975. Also changing economic trends and social conditions have been influential in the development of the theory of multiculturalism. These could be listed as:

- Ethnic and cultural differentiation of the population at large extent due to multiethnic immigration after-of the war,

- Insistent attitude of various immigrants for government support for solution of their living problems,

- Requests for mitigating the speed and extent of immigrant assimilation,

- Expanding of the public sphere by economic welfare.

Although the diagnosis of a multicultural society may have gone through a process that was previously expressed with such terms, as also stressed by Lopez (2000: 27), 'lobbying' can now help immigrants. As one looks at the real life, it can be noticed that the host-country desires a society where African immigrants are employed in lowest-profile jobs while highest ranks are occupied by lawyers, pilots, doctors and bankers who are sons of the host society. The concept of 'multiculturalism' no longer has the association of equality or respect. Moreover, it has moved away from the concerns related with living together.

Muslims all over Europe suffer from the war against terrorism. Asifa Hussain and William Miller (2006) revealed

1 Multiculturalism: Promotion and acceptance of cultural diversity as characteristics of the society. Multiculturalism tries to protect and bless cultural diversity, e.g. minority languages. It also focuses on unequal relationships often faced by minority cultures against the mainstream culture (The Harper Collins Dictionary of Sociology, 1991). it in their studies titled 'Multicultural Nationalism' and they defined the relationship between nationalism and multiculturalism as a natural oxymoron ${ }^{2}$. Also in their research, they found out significant differences regarding Islamophobia between Scotland and England indicating higher levels of hostility against foreigners and Islam in England. Therefore Hussain and Miller emphasized that Islamophobia is closely connected with the British nationalism while it is unrelated with the Scottish nationalism at the same extent. They think that the British nationalism has more 'ethnic' and 'racist' features, while the Scottish nationalism is more 'civil' and 'liveable together' (Hussain and Miller, 2006: 49).

The citizenship understanding and multicultural experience of the German are discussed in relation with "ethnocultural discrimination" by some Occidental writers (Kivisto, 2002: 168), and such discussion is justified with recently witnessing of notable prejudice, discrimination and violence against foreigners in Germany. For example, the events in Rostock, Moelle, Solingen and Madgeburg are just a few of the attacks against Turks.

The French experience of immigrants is also seen to be linked with the French nationalism. Although The French Revolution was realized for brotherhood, equality and justice, it would not be overinterpretation to regard the French ideology of immigrants as an assimilationist 'French melting pot' in connection with nationalism (Kivisto, 2002: 171).

Also as understood from the discussion above, not all European countries display the same perception of the concept of multiculturalism. In Scotland, different ethnic communities are not seen as a threat at one end, while at the other end is France, which sees immigrants as a threat. Germany as a country with nationalism and identity based on "culture" can be assessed similar to France as well (Altınbaş, 2006: 57).

\section{Conclusion}

It seems from the historical situation regarding the European countries and immigrants that in 2015 not much progress has been made from the starting point. Historically, the developed European countries first tried to assimilate immigrants, and then they applied to integration. However, gradual transformation of the integration efforts to assimilation practices also hinders the success of the European multiculturalism put into practice at a later stage. The situation is revealed the most obviously in harshened rhetoric of the extreme right-wing party leaders in various European countries and increased social acceptance rate of such parties.

Decreased birth rate and increase of the elderly population constitutes a really big dilemma for European countries. Increased labor demand of European countries has not yet reached the optimum level. The need for labor is increasing every year. What is experienced by Europe can be interpreted as an approach-avoidance conflict in psychological terms.

2Together use of words with opposite meanings as in the example of thunderous silence, constant variable and systematic chaos. 
European countries need to see that they could not contribute to the solution especially by politicians inciting the people of Europe and fueling nationalism and xenophobia.

It should be realized that Muslims and Turks have a special place in Europe and such a historical status is also perceived by Europeans. Although the existing socio-political and historical conflict could be said to be rooted in historical processes, it would be wrong and too simplistic to reduce explanation of the situation with the thesis of conflict of civilizations.

In reality, the immigrants' efforts for adaptation and compliance are often ignored. In fact, immigrants pose the second most important source of multicultural living in European countries. However, immigrant groups are still referred to with an exclusivist discourse by the host culture. For example, millions of Syrians who migrated to Turkey due to the civil war in Syria are called 'guests' by both Turkish people and Turkish authorities. It is avoided to use the term immigrant or refugee. European countries seem too far from taking up such a sensitive attitude towards immigrants living in their country for many years. Rather, they are referred to as 'foreign' or 'migrant worker' by the host culture, which are alienating concepts meaning staying out of the European unity. Instead, more inclusive and definitions and discourses could be used such as national, ethnic group or ethnic group. Also discrimination and even inferior treatment is still seen to be ongoing in real life. It seems that the concept of multiculturalism put forward after integration and compliance was not also enough to improve the situation.

\section{References}

[1] Asifa HUSSAIN, William MILLER (2006). Multicultural Nationalism (Islamaphobia, Anglophobia and Devolution). New York: Oxford University Press.

[2] Ayşe ÇAĞLAR, Levent SOYSAL. Introduction: Turkish Migration to Germany Forty Years After. New Perspectives on Turkey, vol.28-29, 2003, pp.1-18, Ankara.

[3] BBC NEWS, 2008 French Muslims Face Job Discrimination. BBC World News, November 2, 2005. http://news.bbc.co.uk/1/hi/world/europe/4399748.stm, (Retrieved March 17, 2008).

[4] Charles BOHLEN (2006). France Struggles to Help Immigrants Without Sacrificing Ideals. Bloomberg, December 5.

[5] Deniz ALTINBAȘ 2006. Avrupa ve Çokkültürlülük: Fransa Örneği. Ankara: Stratejik Analiz.

[6] EUMC 2006. Muslims in the European Union, Discrimination and İslamophobia, Austria: Manz.

[7] Hakan Ö. ONGUR. Avrupa'da Çokkültürlülüğün İflası mı?, Uluslararası Hukuk ve Politika, vol.26, 2011, pp.55-85.

[8] Han ENTZINGER (2006). The Paralel Decline of Multiculturalism and The Walfare State in The Nederlands, İn: Keith Banting And Will Kymlicka (eds.). Multiculturalism and The Welfare State: Recognition and Redistribution in Contemporary Democracies. New-York: Oxford University Press.
[9] Hasan POLAT, Federal Almanyada Müslümanlar ve BadenWüttemberg Eyaletinde Alman Vatandaşlığına Geçişte Uygulanan Testlerin Hikayesi, İn: Kadir Canatan and Özcan Hıdır (eds.). Batı Dünyasında Íslamofobi ve Anti-İslamizm. Ankara: Eski Yeni Yayınları, 2007, pp. 329-354.

[10] İbrahim KALIN. Göç, Entegrasyon Ve Avrupa'nın Tarihsel Biricikliği, 2006, From http://www.setav.org/index.php?option=com_content\&task=vi ew\&id=128\&1temid=29. Retrieved March 16, 2009.

[11] İnanç Songülen, Z, Çetin, S 2011. Avrupa'nın Kendine Dönen Silahı: Dışlayacılık ve Ayrımcılık, Ankara: SDE.

[12] İsmail YAVUZCAN. Almanya'da İslamofobi, Bat1 Dünyasında İslamofobi ve Anti-İslamizm. İn: Kadir Canatan and Özcan Hidır (eds.). Batı Dünyasinda İslamofobi ve Antiİslamizm. Ankara: Eski Yeni Yayınları, 2007, pp. 309-329. Eski Yeni Yayınları, Ankara.

[13] Jiirgen, MEİSEL (1990). "Code-Switching And Related Phenomena In Young Bilingual Children", Workshop On Concepts, Methodology And Data, ESF Scientific Networks, Basel, 1.-2. January 1990.

[14] John BURTON (2006). The Struggle for A United Kingdom. The Sydney Morning Herald. December 9.

[15] Joseph FİCHTER (1990). Sosyoloji Nedir? (Çev.: Nilgün Çelebi), Konya: Selçuk Üniversitesi Yayınları.

[16] Kadir CANATAN. Avrupa Toplumlarında Çokkültürlülük, Uluslararası Sosyal Araştırmalar Dergisi, vol. 2, No.6, 2009, pp.80-97.

[17] Ken MOCHİZUKİ. (2005). Muslim İn Europe Why İs İt So Difficult,

www.fcenter.keio.ac.jp/masakoy/awc/2005awc_mochizuki.pdf .Retrieved March 25, 2008).

[18] Liz FEKETE (2008). Integration, İslamophobia and Civil Rights in Europe, London: Institute of Race Relations.

[19] Mark LOPEZ (2000). 'The Politics of The Origins of Multiculturalism: Lobbying and The Power of Influence', The Origins of Multiculturalism in Australian Politics 1945-1975. Melbourne University Press.

[20] Mehmet KUBAT. İslam'ın Barışçı Niteliği ve Batının Onu Şiddet ve Terörle Özdeşleştirme Algısı Üzerine, Akademik Araştırmalar Dergisi, vol.9, No.34, 2007, pp.176-213.

[21] Müşerref YARDİM. Le Pen'leşen Fransız Laisizmi, Perspektif, 2014, pp.13-16.

[22] Nicholas SEMENKOVICH, Muslim Integration and the European Union: A role for immigration restriction. From http://ocw.mit.edu/NR/rdonlyres/History/21H-221Fall2006/F27307E6-F73946E49CEDBA30DEE4BEE5/0/paper_muslim_eu.pdf. Retrieved November 24, 2015.

[23] Olivier ROY. Euro-İslam: The Jihad Within? The National Interest, vol.71, 2003, pp. 63-73.

[24] Orhan TÜRKDOĞAN (1998). Etnik Sosyoloji. İstanbul: Timaş Yayınları.

[25] Özcan HIDIR (2007). Tarihte Bir Anti-İslamist Olarak Martin Luther, İn: Kadir Canatan and Özcan Hidır (eds.). Batı Dünyasinda İslamofobi ve Anti-İslamizm. Ankara: Eski Yeni Yayınları, pp. 145-178. 
[26] Peter ANTES. Avrupa'da İslam, (Çev: Süleyman Turan), Marife, vol. 5, No. 2, 2005, pp. 203-218.

[27] Peter KIVISTO (2002). Multiculturalizm in A Global Society. Malden: Blackwell Publishing Company.

[28] Ramazan KILIÇ. İslam ve Avrupa Entegrasyonu. Liberal Düşünce, vol. 44, 2006, pp. 27-38.

[29] Robin Wilson HAINSWORTH (2012). Les Partis d'Extreme Droite et Leur Discours en Europe: Un défi de notre temps, Bruxelles: ENAR.

[30] Şener AKTÜRK. Türkey's Special Relationship with Germany and Russia. Insight Turkey. vol. 8, No. 4, 2006, pp. $7-13$.

[31] Shireen T. HUNTER. Islam in Europe and The United States,
A Comparative Perspective. Center For Strategic and International Studies, 2002, pp. 11-15.

[32] Talip KÜÇÜKCAN. Bridging The European Union and Turkey: The Diaspora in Europe, Insight Turkey. vol. 8, No. 4, 2007, pp. 55-99.

[33] Tuomas MARTIKAİNEN. Din, Göçmenler ve Entegrasyon, (Çev. Nebile Özmen), M. Ü Ilahiyat Fakültesi Dergisi, vol. 38, 2010, pp263-276.

[34] Watt MONTGOMERY (1989). İslam Avrupa'da. (Çev: Hulusi Yavuz). İstanbul: Marmara Üniversitesi Yayınları.

[35] Yeni Şafak 2006, Pazar. Politika Sayfas1, 17 September 2006, http://yenisafak.com.tr/Politika/?t=17.09.2006\&c $=2 \& i=5870$. Retrieved December 24, 2015. 